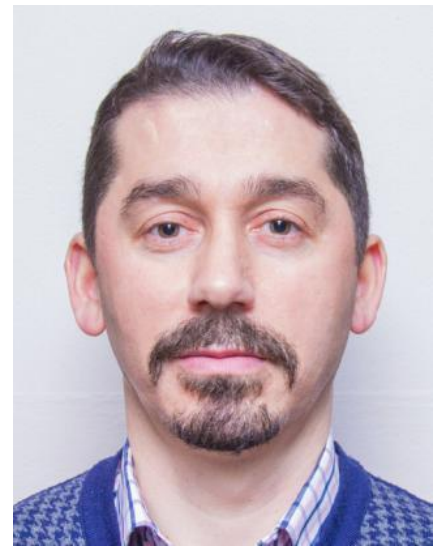

\author{
Іскендер Топчу, \\ аспірант Державного педагогічного \\ університету імені Іона Крянге \\ (м. Кишинів, Молдова)
}

\author{
Iskender Topcu, \\ PhD student, \\ Ion Creanga State Pedagogical University \\ (Chisinau, Moldova) \\ itopcu82@hotmail.com \\ ORCID ID 0000-0001-9732-149X
}

\title{
GAME SITUATION AS A MEANS OF FORMING COMMUNICATIVE COMPETENCES IN STUDENTS
}

Abstract. The article analyzes the role of gaming situations in the process of forming communicative competences in students. A traditional approach to learning is not always justifiable in a modern comprehensive school setting, as it does not adequately provide for intensive acquisition of knowledge.

The use of the game situation system permits effective shaping, improving and developing the skills and abilities for all types of language activities. The game exercises, when used systematically, help to model the conditions of real communication in the learning process, which in turn leads to an increased level of motivation to learn a foreign language.

The situation as a relationship system does not appear arbitrarily. Students can be provided with specific situational positions, so that the situation will arise and function on their basis, thus permitting to plan the necessary for controlled learning situations in advance. The situation is a universal form of the communication process functioning that exists as an integrative dynamic system of social status, role, activity and moral relationships between the subjects of communication, reflected in their minds and arising from the interaction of their situational positions.

In the context of our study, we have defined game situations during foreign language lessons as an active type of educational activity aimed at simulation modeling the systems, processes, and phenomena being studied.

Game exercises with an element of competition provide motivation for learning and speech activities due to participation in game activities. Game situations with a role-based component contribute to enhancing motivation of student participation in foreign language communication in the classroom and formation of students' communication skills. The game situation is the set of tasks that include specially designed learning situations and communicative dialogues that contribute to the design of the process of development of the communicative potential of an individual student.

Keywords: game situations, linguistic activity, communicative competences.

\section{ІГРОВА СИТУАЦІЯ ЯК ЗАСІБ ФОРМУВАННЯ КОМУНІКАТИВНИХ КОМПЕТЕНЦІЙ У СТУДЕНТІВ}

Анотація. У статті проаналізовано роль ігрових ситуацій у процесі формування комунікативних компетенцій учнів. Визначено, що в умовах сучасної школи традиційний підхід до навчання не забезпечує в повній мірі інтенсивне оволодіння необхідною системою знань. Використання системи ігрових ситуацій дозволяє ефективно фрормувати, вдосконалювати і розвивати навички та вміння усіх видів мовної діяльності. Ігровою ситуацією є сукупність завдань, що включають спеціально розроблені навчальні ситуації та комунікативні діалоги, які сприяють розробці процесу розвитку комунікативного потенціалу окремого студента. Студентам необхідно створювати специфічні ситуаційні позиції, щоб ситуація виникла і фрункціонувала на їх основі, що дозволяє заздалегідь планувати необхідні для контрольованих ситуацій навчання.

Ігрові вправи, які використовуються систематично, сприяють моделюванню умов реального спілкування в процесі навчання, що, в свою чергу, призводить до підвищення рівня мотивації вивчення іноземної мови. Ігрова ситуація

$€$ універсальною формою функціонування комунікаційного процесу, що існує як інтегративна динамічна система соціального статусу, ролі, діяльності та моральних відносин між суб'єктами комунікації. У контексті дослідження визначено ігрові ситуації під час уроків іноземної мови як активний тип навчальної діяльності, спрямованої на моделювання моделей систем, процесів і явищ, що вивчаються.

Ігрові вправи з елементом конкуренції забезпечують мотивацію до навчальної та мовленнєвої діяльності через участь у ігрових заходах. Ігрові ситуації з рольовим компонентом сприяють підвищенню мотивації участі студентів у спілкуванні іноземною мовою в класі та формуванні навичок спілкування студентів.

Ключові слова: ігрові ситуації, мовна діяльність, комунікативні компетенції.

\section{INTRODUCTION}

The analysis of pedagogical theory and practice indicates that a traditional approach to learning is not always justifiable in a modern comprehensive school setting since the general rate of study and the amount of knowledge to take in are 
aimed at students of the average level, and large amounts of information are furnished in the ready form through the teachers; in other words, traditional learning does not adequately provide for intensive acquisition of knowledge.

Elimination of this contradiction is possible on condition that the traditional approach to learning is replaced by playful. We define playful learning as a process where students guided by their teacher take initiative and engage in a competitive and energetic cognitive activity in the form of game to acquire knowledge, skills and abilities. This process imitates qualities and conditions necessary to reveal and develop abilities and skills necessary for future life.

Analysis of recent sources and publications. Within a psychological concept of $A$. Leontiev and D. Elkonin, a game is defined as an activity the subject and motive of which lie in the very process of its implementation. Their research showed that games have a particularly big potential for the development of child's intelligence. D. Elkonin defined a game a social by its nature activity that arose from the conditions of child's life in a particular social environment.

Games are recognized and explored by the world psychological community as an important component of cultural development of a child: children's tradition (V. Mukhina), an upbringing practice (E. Subotsky, J. Bruner), an integral part of the people's lifestyle and culture (I. Kon), a way of transferring ethnocultural experience that provides enculturation of a child (M. Mead).

AIM AND TASKS RESEARCH. The aim of the research is to analyze the role of game situations in the process of forming communicative competencies in students.

RESEARCH METHODS: To solve the research tasks, theoretical methods were used: analysis, systematization and generalization of psychological and pedagogical and educational-methodical literature in order to determine the state and theoretical substantiation of the problem of forming communicative competences of students through game situations.

RESEARCH RESULTS

Особливо складна ситуація з фрінансуванням склалася в об'єднаних територіальних громадах у гірських дотаційних областях.

\section{CONCUSSION AND PROSPECTS FOR FURTHER RESEARCH}

The situation as a relationship system does not appear arbitrarily. Students can be provided with specific situational positions, so that the situation will arise and function on their basis, thus permitting to plan the necessary for controlled learning situations in advance. The situation is a universal form of the communication process functioning that exists as an integrative dynamic system of social, status, role, activity and moral relationships between the subjects of communication, reflected in their minds and arising from the interaction of their situational positions.

Interrelation of the game and communication was noticed by O. Gazman, who believes that the game remains the best mastered activity for teenagers, who feel confident in it: they know the methods of communication, ways to set goals, coordinate actions, foresee the result. As a socio-cultural phenomenon, the game is realized in communication, by means of which it is transmitted, organized, and functions. The game is generated by a specific need for communication [4].

It is in the course of the game that opportunities for manifestation of personal activity, for demonstration of one's potential abilities, qualities and communication skills are created. The game provides freedom of action and choice, possibility for selfdetermination, for thinking and expressing one's thoughts, controlling emotions, knowing oneself; it allows everyone to rise above their personal problems in interaction with an outside world.

Communication at school has a meaning deeper than mere contacts between people. V. Grekhnev believes that one of the best ways of organizing active communication during a lesson is a business or situation role-playing game, because positive attitudes toward mastering and practical testing of students' knowledge and certain skills are developed in the course of such games. The game provides conditions for mental adaptation of students to each other [5].

Communicative situations call for the teacher to create such learning situations that allow communicative abilities of students to be revealed and implemented. Types of communicative situations are communicative games, communicative imitations, and free communication.

A game is a peculiar school of communication, during which a child learns the norms of free creative learning behavior. Use of game situations in the educational process allows creation of an accurate model of communication, as it involves imitation of reality.

Communication of students with each other is a very complex and delicate process. Ineffectiveness of communication can be associated with the complete or partial absence of communicative skills, for example, the ability to comprehend and behave in a particular situation.

Analysis of this problem in pedagogical theory and practice allowed forming a number of approaches to the classification of game situations or game exercises. The proposed classification is an attempt to reflect all characteristics of the game and to present it as an effective method of teaching an English class. In our study, we used play exercises that have a significant methodological potential: they provide motivation for learning activities, create positive emotional learning atmosphere and favorable conditions for collective interaction when performing game and study tasks.

A modern foreign language lesson is very intense and requires students to maintain concentration and focus. The use of gaming exercises helps to maintain enthusiasm and high performance throughout the entire lesson.

The lesson should be filled with such game situations that would allow students to alternate their activities. Exploring the process of forming speaking skills, it is necessary to clarify two additional requirements for using game situations in the learning process: the systematic use of game situations as an integral part of the overall system of exercises and complex use of game situations, which are realized by combining several skill forming programs when exercises from different complexes can be successfully used in one lesson or combined into one situation as its components. 
We agree with the opinion of K. Savchenko who views modeling of pedagogical situations as the process of creating situation models that imitate educational process in the course of continuing development of personality that changes in accordance with the requirements for training and reveals the relationship between the participants of the situation that reflect the educational process and are under the guidance of the teacher [1].

In our study, we rely on the opinion of I. Zyazyun, who believes that each pedagogical situation can be modeled differently but the effect of upbringing will directly depend on the knowledge and abilities of the teacher [5].

Presence of numerous hierarchically organized criteria allows characterizing any game exercise from various angles. Game situations are the most effective method of learning, since the introduction of a game element in English classes arouses students' interest in the subject, contributes to rapid learning of new vocabulary material and forming of oral speech skills in a playing environment that is natural for students. Game situation makes the hard work of learning a foreign language fascinating and brings moral satisfaction.

Modeling specific communication situations and their analysis or solving communication problems are designed to enrich students with knowledge of communication, its functions and capabilities, to develop various verbal and non-verbal skills and abilities. A. Matyushkin and M. Postalyuk understand a communicative task as modeling a problematic situation occurring in the process of real communication. Solution of communicative tasks is based on a logical plan developed by the teacher in advance, according to which he monitors and, if necessary, directs the learning situation in the right direction [4].

Games can be used at all stages of learning a foreign language at school, but the content of the language material and the nature of the tasks must be chosen according to age of the students and the level of training of a particular class. At the initial stage of training, special attention should be given to games on simple perception and reproduction of the material, and at the next one on the development of students' ability to identify and compare phenomena and facts, analyze and summarize them, draw the right conclusions and so on. The game is to be chosen by the teacher as he is the only one who can decide on the best option for the students.

We agree with the opinion of I. Danilovich, who came to the conclusion that a game task is a specially organized exercise that requires application of emotional and mental efforts. Game exercises contribute to:

- creating children's psychological readiness for verbal communication;

- ensuring children's spontaneous natural need to repeat language material multiple times;

- training students in choosing the right speech option, which prepares them for situational spontaneity of speech in general [5].

Game is an effective means of learning, which covers various types of speech activity (listening, speaking, reading, and writing), helps students master a foreign language, and enables them to experience emotional satisfaction both in the process of playing and upon achieving the results.

L. Golovchitskaya and N. Skakun express the opinion that conducting foreign language lessons with the use of gaming material activates school children, contributes to achieving high-performance knowledge and fosters love for English language. The games are created in accordance with the requirements of the school curriculum, taking into account the psychological characteristics and cognitive abilities of students; their content is aimed at the development of speech and independent search work of students. Games do not replace other forms and types of work in learning a foreign language but only complement them [4].

Games can be used at various stages of learning English at school, both in class and during extracurricular activities: in the classroom, during competitions, etc. Didactic games combine in them features of gaming and learning activities. When teaching how to speak a foreign language, a didactic game is primarily a student's speech activity, during which they try on various social and interpersonal roles, realizing both verbal and non-verbal means of communication (gestures, postures, facial expressions, and the like).

Management of schoolchildren activity is traditionally referred to as activation. The main goal of activation is the formation of student activity, the improvement of the quality of the educational process. Pedagogical practice uses various ways of activation, the main of which is the use of incentive methods, namely, competing and rewarding.

According to $\mathrm{H}$. Leimits, one of the means of implementing activation of communication is cognitive communication during group work, which requires temporary subdivision of students into groups for the purpose of joint problem solving. Students are instructed to discuss the problem, determine the solution method, implement it in practice and display the result obtained by their joint efforts. Such work ensures consideration of the individual characteristics of the student, presents great opportunities for cooperation and emergence of cognitive communication. Work in groups assumes organization of joint activities leading to the intensification of educational and cognitive processes, mutual enrichment of students within a group, distribution of initial actions, social and cognitive communication, exchange of ways to solve the problem, mutual understanding dictated by the nature of the inclusion of students in joint activities, reflection, through which the attitude to one's own actions is formed and correction is provided. The division into groups can be carried out according to various criteria. For example, a teacher identifies strong, average, and weak students according to their knowledge level and proposes development of special exercises to even their knowledge [1].

As evidenced by the practice of learning foreign languages, didactic games ensure consistency and dynamics of forming linguistic and cultural knowledge in students. The game not only assumes an element of competition, which considerably enlivens the lesson but also brings speech situations as close as possible to real life. Learning games help to make the process of foreign language acquisition interesting and creative. They provide an opportunity to create an atmosphere of interest and to relieve fatigue in high school students. Elements of the game can be introduced into any type of activity during a foreign language lesson, which makes even the most boring work more interesting. 
One of the effective ways to solve the problem of motivation when learning a foreign language is to use game situations. A game situation is an exercise aimed at creating, improving and developing students' skills and abilities in various types of speech activity by repeatedly performing various language actions (operations) that acquire personal meaning for the subjects of learning, since they are motivated to participate in the game activity. Gaming situations have considerable methodological potential: they provide motivation for learning activities, create positive emotional learning atmosphere and favorable conditions for collective interaction when performing game and learning tasks.

Another effective means of solving the problem of learning foreign language communication, namely the means of creating communication motivation, is playing exercises. A game exercise is a specially organized exercise that requires emotional and mental efforts. In a training game or a game exercise, everyone has an equal status. Such a game can be played even by weak students. A student who is weak in language training may become first in the game, as quick wit and ingenuity become more important than knowledge of the subject. The feeling of equality, the atmosphere of delight and joy, the feeling that the task is within the scope of one's abilities, all this helps to overcome shyness that hinders the use of foring language words in speech and provides an adequate level of processing some particular educational material.

We define game exercise as the exercise, the purpose of which is to create, improve and develop students' skills and abilities in various types of speech activity through the repeated and varied execution of speech or language actions that become personally significant for the subject of learning, because they are motivated to participate in the game activity . Game exercises have significant methodological potential: they provide motivation for learning activities, create positive emotional learning atmosphere and favorable conditions for collective interaction during the execution of game and learning tasks.

The study of questions of typology of exercises and provisions of the theory of systems (I. Blauberg, E. Yudin, V. Sadovsky, et al.), the study of a systematic approach to solving methodological problems (I. Bim, V. Skripchenko, et al.) allowed us to develop a system of game exercises which is an integral part of the general system of exercises and methodologically based on the general classification of game exercises.

Analysis of scientific literature and our own teaching experience indicates that didactic games can be actively used in teaching a foreign language, especially in working with high school students. This is due mainly to the following factors: a communicative approach to teaching a foreign language, interests of teenagers, natural need of students for the game.

Taking into account all of the above, we have established that the concept of «game situation» can be expanded by identifying a group of games which prepare students for communicative activity and enrich their vocabulary, and games that provide communicative activity.

Not any gaming activity can be effective. Only the games that are didactically expedient and methodologically justified can be considered the effective means of learning. As was already mentioned, the process of learning a foreign language in a modern school should be aimed at communication. Consequently, the overwhelming majority of forms and types of work, including play activity with students during a lesson, must also be aimed at communication, taking into account age characteristics and interests of school children.

In the context of our study, we have defined game situations during foreign language lessons as an active type of educational activity aimed at simulation modeling the systems, processes, and phenomena being studied.

\section{CONCLUSION AND PROSPECTS FOR FURTHER RESEARCH}

The systematic approach allows effective creation, improvement, and development of skills and abilities in all major types of speech activity. Game exercises, which are used systematically, contribute to modeling the conditions of real communication in the learning process, which, in turn, leads to increased motivation to learn a foreign language. Game exercises with a role-based component contribute to enhancing motivation of student participation in foreign language communication in the classroom.

Game exercises with an element of competition provide motivation for learning and speech activities due to participation in game activities. Game situations with a role-based component contribute to enhancing motivation of student participation in foreign language communication in the classroom and formation of students' communication skills. The game situation is the set of tasks that include specially designed learning situations and communicative dialogues that contribute to the design of the process of development of the communicative potential of an individual student.

\section{REFERENCES (TRANSLATED AND TRANSLITERATED)}

[1] Anikeyeva N. P. (2008) Vospitaniye igroy: uchebnoye posobiye (Upbringing by the game : study guide). Moscow.: Prosveshcheniye. 237 p. (in Russian).

[2] Gavrilova O. V. (2008) Rolevaya igra v obuchenii inostrannykh yazykov (Role-playing game in teaching foreign languages). English. № 1. p. 7-8. . (in Russian).

[3] Zhilkina D. N. (2010) Rolevyye igry na urokakh angliyskogo yazyka (Role-playing games on English lessons). Inostrannyye yazyki v shkole. №1. p. 34- 38. (in Russian).

[4] Panfilova A. P. (2008) Igrovoye modelirovaniye v deyatel'nosti pedagoga: posobiye dlya studentov pedagogicheskikh vuzov (Game Modeling in the Activity of a Teacher: A Handbook for Students of Pedagogical Universities). M.: Akademiya. 223 p. (in Russian).

[5] Selevko G. (2006) Igrovyye tekhnologii (Gaming technology). Shkol'nyye tekhnologii. №4. p. 23-33. (in Russian). 